Article

\title{
Technique, Creativity, and Sustainability of Bamboo Craft Courses: Teaching Educational Practices for Sustainable Development
}

\author{
Ying Dai ${ }^{1, *}$ and Shyh-Huei Hwang ${ }^{2}$ \\ 1 Graduate School of Design, National Yunlin University of Science \& Technology, Douliu 64002, Taiwan \\ 2 College of Design, National Yunlin University of Science \& Technology, Douliu 64002, Taiwan; \\ hwangsh@gemail.yuntech.edu.tw \\ * Correspondence: D10530022@yuntech.edu.tw
}

Received: 31 March 2019; Accepted: 24 April 2019; Published: 28 April 2019

\begin{abstract}
The 18-year history of bamboo craftsmanship in the university curriculum of Taiwan started with the popularization of concepts such as green design, community building, and cultural and creative industries. Bamboo is an environmentally-friendly material that has received much attention in the 21st century. Craftsmanship has drawn the attention of universities. This study uses participatory observation and interviews to collect information on bamboo craft courses in four departments of three universities and uses qualitative coding analysis to explore the sustainable teaching methods of craftsmanship teachers, sustainable development learning effects on students, and different ways of promoting sustainable development education (ESD) with bamboo craft courses in different universities. The research results show the following: (1) There are differences in bamboo craft courses: teachers' craftsmanship and curricula are different, resulting in differences in technical depth and creativity; (2) with respect to the ESD evaluation criteria of the four bamboo craft courses, skills learning itself is not complete, but students are provided with a path to self-reliance in the craft and in responding to cultural sustainability challenges; and (3) regarding the relationship between ESD and bamboo craft education, bamboo craft education promotes the concept of sustainability and is important for the creation of crafts; universities offer opportunities for testing students' technical talents and knowledge, but ESD is limited and blurry.
\end{abstract}

Keywords: education for sustainable development (ESD); green design; craft education; university bamboo craft course

\section{Introduction}

Bamboo craft is a cultural tradition with a long history. With the spread of globalization, it has generally become an important aspect of cultural heritage to show the unique features of different places and symbols of cultural differences. The history of bamboo craftsmanship in Taiwan has evolved as times have changed. In an agro-farming society dominated by kinship and clan groups, bamboo craftsmen mainly worked in areas where bamboo was produced or where bamboo industries congregated. In the early stages of the Industrial Revolution, as the social division of labor became clearer, Taiwan's bamboo products flourished. Bamboo craftsmanship emerged as an important industry during Japanese rule, when many bamboo products, including sanitary chopsticks, bamboo brooms, and bamboo fans, became daily necessities for the populace. Some of these products were exported to Japan and the West [1]. However, the demand for bamboo products dropped dramatically in the 1980s, resulting in a decreasing number of bamboo manufacturers. Soon, only a tiny number of small, household workshops or individual bamboo handicraft practitioners remained, with their focus 
turning to individual workshops or craft teaching [2]. In the age of the internet, bamboo handicrafts not only serve as useful tools in daily life, but they are also becoming endowed with new social functions.

After Taiwan's bamboo industry was transferred abroad in 1980s, the mass-produced bamboo industry began to decline, whereas bamboo craft teaching flourished, resulting in the emergence of the popularity of individually handcrafted bamboo art. In 1994, the Ministry of Culture of Taiwan began to promote the policy of "community building". Guided by this policy, farmer associations and town offices in bamboo-producing areas provided courses on bamboo craftsmanship to train local talent in the technical art of bamboo handicraft, aiming to promote local economic productivity and beautify their homeland [3]. After the adoption of the "Convention on the Protection of Intangible Cultural Heritage" by UNESCO in 2003, Taiwanese society also began to pay more attention to the diverse forms of its cultural heritage. The United Nations Decade of Education for Sustainable Development (DESD, 2005-2014) was a global movement that sought to transform education policy, investment, and practice. Spanning from 2005 to 2014, the ultimate goal of the DESD was to engage people and communities in meaningful, lifelong learning processes that examine how societies can live in more sustainable ways [4]. In 2002, bamboo craftsmanship education was given new opportunities and visibility in Taiwan's colleges and universities thanks to two consecutive plans for cultural and creative industry launched by the Ministry of Culture to promote the bamboo craft industry [5]. However, facing continuing global industrialization and the impact of the information industry, Taiwan's bamboo craftsmanship remains haunted by poor product innovation, the lack of new learners, and the inability to achieve large-scale production. Thus, with respect to bamboo craftsmanship, both culture and industry are urged to identify and groom more new talent [3].

This study explores the teaching practice and promotion methods of bamboo craft courses in universities as related to the concept of sustainable development education (ESD), including the value of disseminating techniques and knowledge, learning effectiveness of students, and the role of craft courses.

Based on the above, this study aimed to do the following:

1. To analyze the differences in teaching practices used in four bamboo courses through in-depth interviews and observations.

2. To analyze the different bamboo craftsman teaching curricula and student learning in the four bamboo courses as related to sustainable development through EDS evaluation criteria.

3. To obtain a clear understanding of the relationship between ESD and bamboo craft education in light of ESD theory by surveying bamboo craft courses.

\section{Literature Review}

\subsection{Education for Sustainable Development(ESD) and Green Design}

As the global environment changes rapidly and society develops, the environmental and social problems facing every locale, such as the decreasing number of natural plants, emerge in an endless stream. As a result, people are calling for increased natural protection [6]. In the 1960s, Victor Papanek said in his book Design for the Real World: Human Ecology and Social Change that designers should take into account the limited resources of the Earth and protect our environment [7]. In 1987, Gro Harlem Brundtland published a report on Our Common Future (also known as the Brundtland Report) at the UN General Assembly. In this report, "sustainable development" was defined as follows: "Sustainable development is a development model that meets our current needs without compromising the needs of future generations to meet their needs" [8]. From 1987 to 1992, the concept of sustainable development matured as committees discussed, negotiated, and wrote the 40 chapters of Agenda 21. Initial thoughts concerning ESD were captured in Chapter 36 of Agenda 21, "Promoting Education, Public Awareness, and Training" [9]. Since the 1980s, the concepts of "environmental protection" and "green design" have gradually become some of the mainstream design concepts in Taiwan. The government invited foreign experts to describe the future design trends of "green design". In 1994, the Industrial Bureau of 
the Ministry of Economy promoted the "Application and Promotion Plan of Green Design" and then formally published the book Green Design [10]. The importance attributed by the government, industry, and non-governmental organizations to the environment has also inspired serious thought in the field of design. Teachers and students in the design departments of universities are developing products for environmental protection, paying attention to the rational use and recycling of materials, and producing goods without pollution or with low pollution to the environment. From the late 1980s to 1990s, a large number of traditional handicraft factories were closed, coinciding with the emerging community effort to incorporate traditional handicraft into community education [11]. Since the 1990s, schools have designed educational models and technical curricula for handicraft courses, which are essentially similar to traditional crafts. During this time, traditional crafts were formally introduced into the curricula of universities, where students learn craftsmanship by creating products that combine crafts with life [12]. Competence-based higher education enables students to gain important knowledge, skills, values, and attitudes, which they will require in their future professional and personal lives [13]. Rychen (2002) affirms that the use of competence-based education contributes to improving the process of assessing students regarding the abilities they acquire to face life's challenges, but also sets key educational goals that improve education systems and lifelong learning processes [14]. The formal, traditional curriculum is more centered upon the transmission of knowledge, rather than the facilitation of critical, innovative, and creative learning spaces where students can challenge their own models of thinking and practice, develop their own innovative and creative projects, or explore alternative ideas and choices [15]. Weinert affirms that "the theoretical construct of action competence comprehensively combines those intellectual abilities, content-specific knowledge, cognitive skills, domain-specific strategies, routines and subroutines, motivational tendencies, volitional control systems, personal value orientations, and social behaviours into a complex system" [16]. The emotional system controls the muscles of the body and changes the brain's response through chemical neurotransmitters. Positive emotion arouses curiosity, helps stimulate creativity, and keeps the brain open for efficient learning [17]. Research into commonly adopted ESD pedagogies in higher education-adapted from Cotton and Winter (2010)—includes the following: role playing and simulations; group discussions; stimulus activities; debates; critical incidents; case studies; reflexive accounts; critical reading and writing; problem-based learning; fieldwork outdoor learning; and modeling good practice [18]. ESD helps to develop the capacity for critical reflection and systemic and future thinking, as well as to motivate actions that promote sustainable development [19].

In 2002, William McDonough and Michael Braungart began to promote the concept of cradle to cradle, which advocated that humans should learn from nature and that everything is a nutrient and can return to nature. In the pursuit of ecological benefits, the cradle-to-cradle design follows three principles: waste elimination, renewable energy and carbon management, and diversity creation [20]. In response to the German environmental protection scholar's cradle-to-cradle design concept, the National Taiwan Craft Research and Development Institute held a Taiwan Bamboo Craft Exhibition with a "Bamboo Craft and Green Earth" theme in 2009 to encourage people to use their creativity to create a green and fashionable bamboo culture [21]. Considering that people are drifting apart from nature, the environmental friendliness of bamboo materials and its value in a circular economy make bamboo precious in environmental conservation. Bamboo has a short growth cycle, quick harvest and supplement in a short span of time, and no negative impact on the environment. The whole bamboo plant, ranging from its leaves and branches to tubes and roots, can be fully utilized [22]. According to the website of the Bamboo Project Research Center of Musashino Art University, Japan, bamboo design workshops of different themes have been held with regularity since 2008. In Indonesia's post-disaster reconstruction, teachers and students from Japan and India made a variety of sustainable bamboo furniture and bamboo buildings to promote the development of the local bamboo industry [23]. The local wetland of Chenglong Village, Kouhu Township, Yunlin County, is an environmental learning field. Since 2010, Yunlin County Kuanshu Educational Foundation has been commissioned to organize "Cheng-Long Wetland International Environmental Art" annually, inviting international artists and 
residents to share their concerns on environmental issues. The materials used in these environmental art installations are bamboo, driftwood, and other natural materials and recycled materials without environmental hazard [24].

\subsection{Craft Education and Teaching Practice}

The training of Taiwanese technicians in schools began with the Nantou County Technology Research Course, which was held by Gan Sui-Liong from 1954 to 1958. In 1953, the Department of Industrial Education of the National Taiwan Normal University established the Technology Education Group. From the 1960s to 1980s, Gan Sui-Liong, who was regarded as the father of Taiwanese craftsmanship, developed technical talents in universities and colleges, such as the National Taiwan University of Arts [25]. In 1994, the school was restructured, and the department of art industry was renamed as the department of craftsmanship, one of the few university departments in Taiwan that retained "crafts" in the name [26]. Since the 1990s, schools in Taiwan have designated courses similar to traditional craftsmanship, such as model making, craftsmanship, and practical ability training [12]. However, the courses mainly focused on artificial material techniques, including plastics, metal, and glass. Natural materials were more popular in workshops with pedestrian equipment, where bamboo, rattan, or hemp were rarely seen. This contrast shows the scarce attention paid by universities and colleges in Taiwan to crafts of natural materials that demonstrate local culture and wisdom in 1990s. In the 21st century, the traditional apprenticeship has gradually disappeared, and the inheritance of such technique has gradually extended from folk workshops to government departments in charge of cultural vocational training and colleges and universities. Thus, the sites of technological knowledge transfer have changed [27].

Since 2005, the National Taiwan Craft Research and Development Institute has promoted the "Local Craft Characteristic Counseling-Community Craft Support Plan". It has been 13 years since craftsmen cooperated with university teachers and students to promote craft learning in the community, develop local craft products, and increase craft production to foster local industries [28]. These initiatives have led university teachers and students to study in the community, through which professional design departments have obtained creative ideas and knowledge on site by collaborating with local industrial units to design cultural commodities, itinerary programs, and community public spaces, especially the "Yii Craft Fashion Plan" (Cross-domain Creative Application Plan for Craft New Appearance) that was promoted by the Technology Research and Development Center and Taiwan Creative Design Center for five consecutive years from 2008 to 2013. In this event, a large number of works created via collaboration by bamboo craftsmen and designers won high praise in international exhibitions, such as those in Milan, Paris, and New York [5]. Since 2008, the National Taiwan Craft Research and Development Institute has launched a program of "new interest in craftsmanship" to train new-generation craftsmen through the tripartite cooperation of craftsmen, teachers, and students of college design departments [29]. However, each young person is in close contact with a craftsman for at most six months according to the plan. Although these various projects give young people access to bamboo and a deeper understanding of the concept of sustainability regarding the bamboo craft, the communication of craft education is short and not long-lasting, and the teaching of technique and knowledge is shallow and not deep. Such a fragmented craft learning process makes education regarding sustainability scattered and concealed.

As part of general education, craftsmanship education aims to give students access to materials and tools, sparking students' interest, familiarizing students with operations through design and methods, and cultivating their personalities. In doing so, students understand the relationship between products, labor, society, and economy and gain the experience of industry development, family life, and interest. The value of craftsmanship education lies in the real experience, personality exertion, common participation, independent creation, cultural inheritance, observation and experiment, and physical and mental integration [30]. The craft teachers' works feature skills and creativity so that students can see the work, hear the teacher's interpretation of the work, propose creative questions, 
have space for self-expression in their own practice, and turn the creativity into real objects and specific practice [31]. Students are inspired to be creative through practice and study according to the needs of daily life, recognize the characteristics of bamboo processing, and appreciate and apply its value [32]. The best learning method is to provide students with access to the most primitive first-hand data or works and to experience the combination of physical strength and intelligence in artistic creation [33].

\section{Methods}

The bamboo craftsmanship courses in universities are influenced by factors such as the geographical location, operation conditions, and faculty of a university; therefore, the skills and concepts imparted by bamboo craftsmen and the needs of students are so complex and diverse that teaching methods vary from one department to another. Therefore, this study adopts a qualitative research method to conduct in-depth observations and inquiries regarding on-site teaching, observe and analyze the cognition of teachers and students with respect to learning bamboo craftsmanship, and perform qualitative research, aiming at establishing relationships with the subjects and sampling, collecting, and analyzing data. These factors will have an impact on the value and validity of the research conclusions [34].

The research process is divided into three parts, as shown in Figure 1. Part 1 is pre-preparation and field observation, part 2 is course observation period and data collection, and part 3 is analysis of course records and interview data. The detailed research process is as follows.
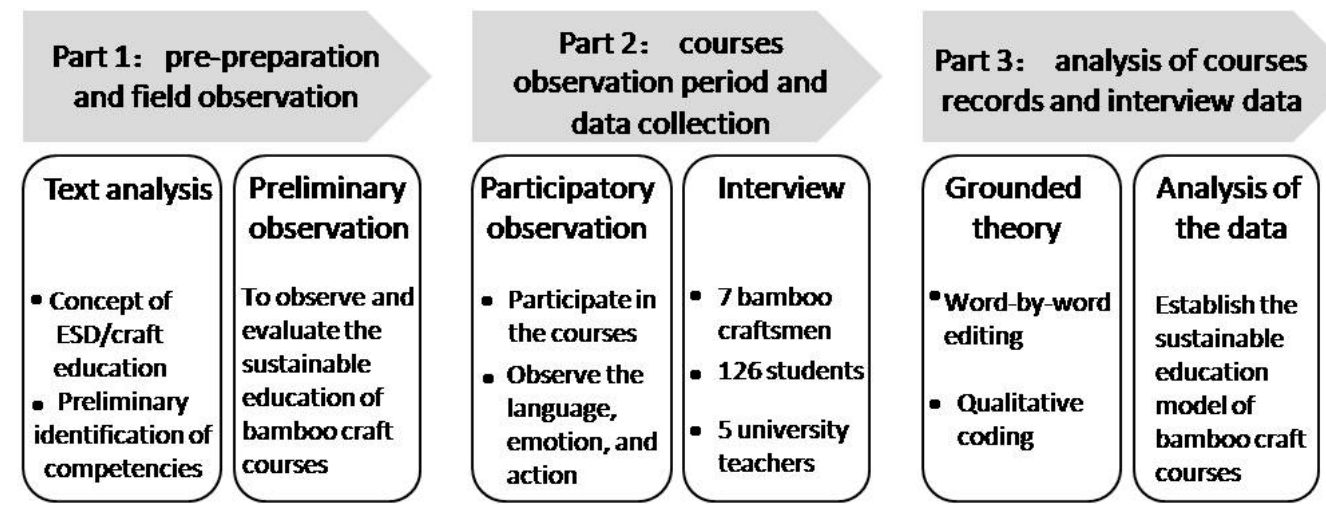

Figure 1. Research methodology (three parts). ESD: education for sustainable development.

- Part 1 focuses on the teaching of bamboo craft courses in universities and used a text analysis method to collect relevant research works, academic journals, special reports, news reports, and website content. Following the collection, the subjects of the course were observed in teaching sites, and the class atmosphere was evaluated to gain the trust of the subjects and adjust the subjects of study.

- Part 2 features the participatory observation method through which researchers participated in the course personally to observe and record the teaching process, course content, and teacher-student interaction in bamboo craft teaching. Students of the course participated in semi-structured interviews to indicate their motivation for taking the course and their early impressions of bamboo materials.

- Part 3 adopts the grounded theory to extract details and connotations and conduct qualitative analysis of word-by-word editing and images to put researchers in the real situation of class teaching.

In a study with limited resources and conditions, under the guidance of the sustainable development education literature, data was collected through participatory observation, in-depth interviews, social platforms, and literature review, and data collection stopped when the viewpoints of data presentation were saturated. In an in-depth interview, the Department of Cultural Heritage Conservation was used to study resource and condition constraints. The Department of Cultural 
Heritage Conservation and Department of Creative Design at National Yunlin University of Science and Technology offers a long-term, two-year track program in which researchers participated in class as students to see the panorama of bamboo craftsmanship curriculum in the university with respect to different aspects of technique and creativity and to supplement new information.

The "bamboo craftsmanship" discussed in this study refers to the craft of bamboo plaiting, bamboo carving, and bamboo tube furniture building, rather than the mechanical or deep-processing of bamboo laminates, bamboo charcoal, bamboo paper, or bamboo fibers. When the keyword of "bamboo" is used to search for courses on the websites of universities and colleges, the earliest course related to bamboo craftsmanship after 2000 was "bamboo craftsmanship" offered by the Plastic Art Department of Da-Yeh University in 2001 [35]. This study was conducted from October 2016 to November 2018, when four departments of three universities in Taiwan offering courses related to bamboo craftsmanship were selected as the subjects of study, including the Department of Cultural Heritage Conservation and Department of Creative Design, National Yunlin University of Science and Technology(YC/YD); the Department of Leisure, Recreation, and Tourism Management, Southern Taiwan University of Science and Technology(STL); and the Department of Tea and Ceramic, Asia-Pacific Institute of Creativity(APT). During the study, National Kaohsiung Normal University and National Chung Hsing University also offered bamboo courses, but the courses offered by the Department of Industrial Design, National Kaohsiung Normal University and the Department of Forestry, National Chung Hsing University were excluded from the study due to their respective focuses on wood craftsmanship and mechanical processing of bamboo materials. The course offered by the Department of Crafts and Design, National Taiwan University of Arts was also not included in the study given that the bamboo craftsmen of this course did not respond during the research and did not personally participate in the course observation and in-depth interviews. Among the subjects of the study, the bamboo craftsmen talked about the characteristics of university technique teaching; students mainly talked about how they perceive their learning experience and how they master techniques; and the university teachers mainly talked about the ideas of school craft curriculum, as shown in Table 1.

Table 1. Basic information of interviewees for the teaching of bamboo craftsmanship.

\begin{tabular}{|c|c|}
\hline Code of Course & Code of Interviewees (Personal Background, Date of Interview) \\
\hline $\begin{array}{c}\text { YC (Department of Cultural Heritage Conservation, National } \\
\text { Yunlin University of Science and Technology) }\end{array}$ & $\begin{array}{l}\text { - YC-C01(Craftsman in a course on bamboo plaiting at YC, } \\
\text { 2016/10-2018/11) } \\
\text { - YC-C02(Assistant of craftsman for a course on bamboo plaiting } \\
\text { at YC, 2016/10-2018/11) } \\
\text { - YC-C03(Graduating from YC, ex-teaching assistant for bamboo } \\
\text { plaiting course after graduation, 2017/05/05 and 2018/01/03) } \\
\text { YC-S01-33(Students from different grades of the same } \\
\text { department at the university in a course on bamboo plaiting at } \\
\text { YC, 2016/10-2018/11) } \\
\text { - YC-T01(Professor, YC, 2018/01/10) } \\
\text { - YC-T02(Office assistant at YC, 2017/12/13) }\end{array}$ \\
\hline $\begin{array}{l}\text { YD (Department of Creative Design, National Yunlin } \\
\text { University of Science and Technology) }\end{array}$ & $\begin{array}{l}\text { - YD-C01(Craftsman in a course on bamboo design at YD, } \\
\text { 2016/10-2018/11) } \\
\text { YD-S01-45(Students from different grades of different } \\
\text { departments in a course on bamboo design at YD, } \\
\text { 2016/10-2018/11) } \\
\text { YD-T01(Professor, College of Design, National Yunlin } \\
\text { University of Science and Technology, ex-dean of YC, } \\
\text { 2018/05/29 and 2018/09/18) }\end{array}$ \\
\hline
\end{tabular}


Table 1. Cont.

\begin{tabular}{|c|c|}
\hline Code of Course & Code of Interviewees (Personal Background, Date of Interview) \\
\hline $\begin{array}{c}\text { STL (Department of Leisure, Recreation, and Tourism } \\
\text { Management, Southern Taiwan University of Science and } \\
\text { Technology) }\end{array}$ & $\begin{array}{l}\text { - } \quad \text { STL-C01(Craftsman in a course on bamboo DIY at STL, } \\
\text { - } \quad \text { STL-C02/(Graduate of STL, teaching assistant for a bamboo } \\
\text { plaiting course after graduation, 2018/03/08 and 2018/05/09) } \\
\text { - STL-S01-18(Junior and senior students of different departments } \\
\text { in a course on bamboo DIY at STL, 2018/03/09) } \\
\text { - STL-T01(Associate professor, Department of Creative Product } \\
\text { Design, Southern Taiwan University of Science and Technology, } \\
\text { multiple participation in the theme of "new interest in } \\
\text { craftsmanship", 2018/03/09) }\end{array}$ \\
\hline $\begin{array}{c}\text { APT (Department of Tea and Ceramic, Asia-Pacific Institute of } \\
\text { Creativity) }\end{array}$ & $\begin{array}{l}\text { - } \quad \text { APT-C01(Craftsman in a course on bamboo craftsmanship at } \\
\text { APT, 2016/11/12 and 2017/12/15) } \\
\text { APT-S01-30(On-the-job students and common students in a } \\
\text { course on bamboo craftsmanship at APT, 2017/12/15) } \\
\text { - APT-T01(Teacher of the department of Asia-Pacific Ceramic Art } \\
\text { Design, 2017/12/06) }\end{array}$ \\
\hline
\end{tabular}

\section{Results and Discussion}

This chapter mainly discusses the teaching methods, learning effectiveness, and methods of promotion regarding bamboo craftsmanship courses from October 2016 to November 2018offered by the following departments and institutions: YC; YD; STL; and APT. The following analysis will begin with teaching practices, followed by student learning, and promoting ESD competencies.

\subsection{Teaching Practices of Four Departments of Three Universities: Dissemination of Knowledge, Techniques, and Creativity of Bamboo Craftsmanship}

4.1.1. YC: Learning Complete Advanced Bamboo Plaiting Techniques through Serial Courses Covering Bamboo Processing, Bamboo-making Machines, and Spray Painting

Bamboo can be processed into thin strips or sheet materials for bamboo plaiting, commonly known as bamboo strips. The processing procedures of bamboo strips include selecting materials, sawing bamboo, pruning, scraping, dividing, splitting, setting the width, thinning, and chamfering [36]. In this study, YC is the only department that teaches students bamboo processing. Teachers provide students with the boiled insect- and mold-free bamboo pipes in advance for the learning of follow-up bamboo processing. This is closely related to how bamboo craftsmen begin work on bamboo art. Subject YC-C01, a craftsman, believes that the "bamboo cutting technique is the most fundamental technique of bamboo plaiting, and only by mastering bamboo cutting technique can bamboo be woven independently. The process is complex and highly technical, resulting in the difficult inheritance of bamboo plaiting" (respondentYC-C01, 2018/05/29). Considering that students can select different courses at the four-year university, teaching bamboo technique during university is a sustainable practice; craftsmen offer serial bamboo plaiting courses of (1)-(8) each semester. Students who are really interested in bamboo plaiting may take related courses from freshman year to senior year and graduate after having learned the technique for three years and four months, as required by the traditional apprenticeship system. In doing so, they have the opportunity to master a set of techniques in bamboo plaiting within four years. However, this will cause the level of bamboo plaiting techniques to vary in the same course, which requires teachers to teach students of different ages.

The bamboo plaiting of students in the same semester can be divided into three different levels. All students have class in one area of the classroom for demonstration guidance and peer learning. The teaching process is roughly as follows (Table 2): (1) The teaching assistant asks beginners to use machines to cut bamboo bars with which they make some objects, such as a fruit tray, round bowl, or basket, so that they learn better the warp and weft of bamboo plaiting and practice the techniques of character plaiting, roulette plaiting, and brush raw lacquer; (2) YC-C02 instructs students who 
take the course for the second or third time to cut bamboo strips, while beginners are required to practice cutting a bamboo strip, and students who cut bamboo bars for the second time are asked to practice cutting two bamboo strips; and (3) YC-C01 is responsible for helping students at the first two levels to solve difficult problems. YC-C01 will help students who have taken bamboo plaiting courses without completing their works to finish the course. YC-C01 controls the overall progress of all students, arranges different learning tasks for different classes, evaluates the materials they need, and demonstrates techniques. The teaching assistants are mainly in charge of individual counseling, action demonstration, and material preparation. In the teaching process, teachers and teaching assistants will also discuss difficulties in key steps to explore better and faster ways of teaching.

Table 2. Teaching of bamboo craftsmanship (three levels).

Three Levels
$\begin{gathered}\text { Primary level } \\ \text { (beginner) }\end{gathered}$

4.1.2. YD: Knowing Features of Bamboo Materials and Having Fundamental Shape-making Ability in Bamboo Craftsmanship for Dependent Design of Cultural Commodities

The instructor YD-C01has participated in the technical fashion plan promoted by the Technological Development Center and has cooperated with many designers to design and produce bamboo-themed works that have won international awards. YD-C01 noted that "designers think about the direction of aesthetics and create an atmosphere, but craftsmen have to consider the structure and function, so the design can be implemented only if the two are coordinated and communicated" (respondent YD-C01, 2018/09/17). "Bamboo Art Design" is an optional course for senior students in the field of cultural commodity design, offering2 credits per semester. Students can also take the craft courses of metal-working, ceramics, glass, and woodwork in the first three years of study. Teachers have rich experience in bamboo-shape bending and international cultural creation. They mainly teach bamboo shape-making skills and design methods for students who are design-oriented and design for cultural commodities.

In the first two weeks of the course, YD-C01first demonstrates making more than 10 pieces of bamboo toys to students. This is the real teaching material. The instructor also uses slides to explain traditional bamboo crafts, the application of modern bamboo crafts, and cases of creative design of bamboo crafts. The teacher asks students to operate and experience these physical teaching materials while explaining the stories and crafts contained in them. Students' interest in bamboo art is sparked by playing with bamboo. Students who have spare time are also encouraged to learn making other 
bamboo crafts: (1) bamboo-woven fish, learning the simplest way to make a three-dimensional shape and color painting decoration; (2) bamboo-balanced birds, the ability to cut and slash the bamboo with a knife and to understand the relationship between the control of upper strength and angle and the change of bamboo shape, as well as bamboo heating and bending; and (3) eyeglass frames, conducive to learning pentagonal plaiting and free plaiting, is a unit component of modern bamboo household products.

\subsubsection{STL: Simple Bamboo Art DIY to Foster Bamboo Art Aesthetics and Disseminate Bamboo Culture}

STL-C01 said, "At the beginning, it was a co-operation between production and learning on a leisure farm. During the cooperation, we trained several students. They would teach tourists with spare time to learn bamboo plaiting, and these teachers earned good reputation from tourists, so the university was told that the students met the current needs very well" (STL-C01, 2018/03/07). Thus, the bamboo art course was held at STL to combine the leisure industry with technique, add a personal touch to a large number of manufactured products, and use traditional materials in daily life to bring deep feelings to consumers. In the past, bamboo was available everywhere. After the Industrial Revolution, different thinking regarding daily necessities emerged, and bamboo products were found to mold easily if not handled properly. As a result, consumers were less likely to demand bamboo products, and they gradually disappeared from our daily life.

In the beginning of the course, the main consideration is the technological needs of the department. Later, considering the needs of the students selecting this course, graduated students also contribute ideas. Then, teachers put the adjusted teaching content regarding bamboo art into later courses. STL-C01 intends to cultivate people who understand bamboo culture and consumers of bamboo products and increase the motivation for bamboo craft inheritance. Teachers prepare long-branch bamboo strips and related DIY accessories from Tainan. In each weekly two-hour course, students can work on a different type of bamboo art, completing it as much as possible, and can make more than 10 works of DIY bamboo plaiting in a semester. The required tools are only scissors, spray kettles, pins, and cones. STL-C01 is mainly responsible for explaining the relationship between bamboo growth characteristics and utilization, bamboo in different parts of Taiwan and the distribution of the bamboo industry in Taiwan, and the supplementing of other techniques. STL-C02, the teaching assistant, demonstrates every single step of bamboo plaiting for the students, such as creating bamboo rings and balls.

\subsubsection{APT: Simple and Basic Techniques for Free-shape Changes; Slow-paced Life with Tea}

APT specializes in cultivating creative talents for tea and ceramics to improve people's quality of life with respect to tea and taste. Through the teaching of the manual chopping of bamboo strips and basic bamboo plaiting techniques by bamboo artists, these ceramists and tea businessmen are guided to create bamboo wares that can improve the aesthetics of living spaces. In doing so consumers can experience a variety of features offered by bamboo, such as flexibility, warmth, and environmental protection, and understand and cherish the compatibility between traditional and modern bamboo art.

APT-C01 asks students to produce 2-3 pieces of work in one semester. Every two weeks students will learn techniques of basic square-mouth plane plaiting and wheel-mouth plaiting for three hours. In the first lesson, the teacher brings more than 20 pieces of bamboo crafts collected from foreign countries, such as Indonesia, Japan, and Thailand. At the same time, he shows students his works from different periods and introduces changes in bamboo craftsmanship and people's living requirements. In the second lesson, the teacher begins to teach students to understand bamboo materials and to demonstrate the process of bamboo strip processing in turn. APT-C01 demonstrates the process of bamboo stripping while explaining the material treatment methods to students, such as being careful not to leave scars on bamboos because scars affect the skin of bamboo strips and make bamboos more fragile in plaiting. Next, students are taught basic plaiting and free shaping. APT-C01 said: "This time I teach square plane plaiting that can be applied to flower-related tools and lamps, instead of dense 
plaiting or random shaping. Firstly, shape with wire, then bind with rattan core, first shaping, then wrapping with rattan skin. I have woven bamboo for more than 40 years and the first 30 years were very bitter. I was using the traditional method and then with this, so I am interested in the variety of bamboo in large or small quantities" (APT-C01, 2017/12/15).

4.1.5. Summary: Comparison of Teaching Practices of Bamboo Craft Courses in Four Departments of Three Universities

The teaching practices in the university classes on bamboo art with bamboo craftsmen vary (Table 3) with respect to perspectives on teaching purposes and the curricula used to convey knowledge, technique, and creativity relating to bamboo art. These analyses provide a reference for the next section and the assessment of ESD competencies.

Table 3. Comparison of teaching practices of bamboo craft courses in four departments of three universities.

\begin{tabular}{|c|c|c|}
\hline Department & Teaching Purpose & Teaching Content \\
\hline YC & $\begin{array}{l}\text { Mastering the core foundation of } \\
\text { bamboo dissection and learning } \\
\text { basic plaiting techniques and } \\
\text { advanced serial courses of refined } \\
\text { techniques. }\end{array}$ & $\begin{array}{l}\text { Understanding material tools, practicing } \\
\text { bamboo cutting techniques, and learning } \\
\text { bamboo plaiting. }\end{array}$ \\
\hline YD & $\begin{array}{l}\text { Familiarity with material } \\
\text { characteristics, basic bamboo } \\
\text { shaping ability, and independent } \\
\text { design of cultural commodities. }\end{array}$ & $\begin{array}{l}\text { Simple bamboo plaiting techniques, bamboo } \\
\text { cutting and bending skills, and transformation } \\
\text { and application of process design. }\end{array}$ \\
\hline STL & $\begin{array}{l}\text { Simple bamboo art DIY, } \\
\text { cultivating bamboo art aesthetics, } \\
\text { and disseminating bamboo } \\
\text { culture. }\end{array}$ & $\begin{array}{l}\text { Understanding bamboo culture, materials, and } \\
\text { techniques and experiencing bamboo art } \\
\text { practice. }\end{array}$ \\
\hline APT & $\begin{array}{l}\text { Simple basic techniques, } \\
\text { free-shape change, and enjoying a } \\
\text { slow-paced life with tea pottery. }\end{array}$ & $\begin{array}{l}\text { Introducing bamboo art knowledge, } \\
\text { demonstrating bamboo processing, and } \\
\text { practicing basic techniques of bamboo plaiting. }\end{array}$ \\
\hline
\end{tabular}

4.2. EDS Evaluation Criteriaof Four Bamboo Craft Courses(YC, YD, STL, APT): The Different Bamboo Craftsman Teaching Contents and Student Learning Effects of Sustainable Development Recognition

4.2.1. ESD Evaluation Criteria of Four Bamboo Courses: The Different Bamboo Craftsman Teaching Contents of Sustainable Development Recognition

When YC was newly established, the study of handicraft was the foundation of cultural heritage for cultural sustainability, especially looking to the future when students will be engaged in the restoration 
or preservation of cultural relics and management. Therefore, currently, several optional courses of handicraft are offered, including woodcarving, lacquer-ware, bamboo plaiting, and sculpture modeling. Teachers equipped with professional traditional skills have been hired. Courses of bamboo craft, wood carving and sculpture modeling are all given in a special craftsmanship classroom, with a special tool cabinet equipped with a complete set of tools, including a scraper, chopper, clamp, thinner, chamfer, and spray kettle, as well as a cutting machine, grinding wheel, and some mechanical equipment.

YD, aiming to train talents of creative design and local design, offers various optional craftsmanship courses, such as metalworking, ceramics, glass, and bamboo. The professor of the Design Institute mentioned that "at the beginning of the department, these craftsmanship courses were offered to let students know that craftsmanship is more than plastics and metals. Not only can modern materials be used to design objects, but also different kinds of materials. Later, it was found that students would use bamboo to design large objects and cooperated with teachers to participate in IF, Reddot and New Generation Design Competition" (Interviewee YD-T01, 2018/05/29).

In 2013, the bamboo art course was offered in response to the needs of STL students with regards to market experience. The teaching focuses on the cultural education of bamboo technique so that students can master basic knowledge and understand Taiwan's bamboo craftsmanship culture, such as the significance of Guanmiao in Tainan-home to long-branch bamboo. The Department of Creative Product Design did not offer specialized craftsmanship courses, but it did offer optional courses, such as technical design and technical creation. To prepare for these courses and the need for graduation projects, students will choose technical courses in other departments to supplement their knowledge.

In order to enhance the professionalism of tea and ceramics professionals in Taiwan, APT extended the recruitment of tea and ceramics experts, set up first-class professional equipment and sites, and invited bamboo plaiting technicians to verify and test the sites. In 2015, Hsien-ping Chang was invited to lecture on-the-job students and full-time students in the Department of Tea and Ceramic every week. Students are taught how to make flowers or lanterns for tea space arrangement.

These four departments set up bamboo craft courses under different contexts, and the educational development methods of knowledge, culture, natural attributes, creativity, design, and life applications are different. Undergraduate students have the opportunity to learn one or more traditional Taiwanese crafts. Table 4 shows the ESD evaluation criteria that emerged from analyzing the bamboo craftsman' interview responses and behaviors relating to knowledge, practical skills, ethical values, system thinking, and emotions.

Table 4. Evaluation criteria of the four bamboo courses: results obtained from observation and interviews with bamboo craftsman.

\begin{tabular}{|c|c|c|c|c|c|}
\hline Category & Subcategories & YC & YD & STL & APT \\
\hline \multirow{6}{*}{ Knowledge [15] } & Knowledge of cutting bamboo strips & $\sqrt{ }$ & & & \\
\hline & $\begin{array}{c}\text { Knowledge of bamboo species and } \\
\text { characteristics }\end{array}$ & $\sqrt{ }$ & $\sqrt{ }$ & $\sqrt{ }$ & $\sqrt{ }$ \\
\hline & Knowledge of bamboo plaiting & $\sqrt{ }$ & $\sqrt{ }$ & $\sqrt{ }$ & $\sqrt{ }$ \\
\hline & $\begin{array}{l}\text { Knowledge of using a knife to make the } \\
\text { shape of a bamboo tube }\end{array}$ & & $\sqrt{ }$ & & \\
\hline & $\begin{array}{c}\text { Knowledge of using fire to make } \\
\text { skewers }\end{array}$ & & $\sqrt{ }$ & & \\
\hline & $\begin{array}{l}\text { Knowledge of bamboo surface } \\
\text { treatment techniques }\end{array}$ & $\sqrt{ }$ & $\sqrt{ }$ & & \\
\hline \multirow{4}{*}{ Practical skills [18] } & Bamboo cutting skills & $\sqrt{ }$ & & & \\
\hline & Tool usage & $\sqrt{ }$ & $\sqrt{ }$ & & \\
\hline & $\begin{array}{l}\text { Execute the basic rules of bamboo } \\
\text { plaiting }\end{array}$ & $\sqrt{ }$ & $\sqrt{ }$ & $\sqrt{ }$ & $\sqrt{ }$ \\
\hline & $\begin{array}{l}\text { Understand the applications of bamboo } \\
\text { in life }\end{array}$ & $\sqrt{ }$ & $\sqrt{ }$ & $\sqrt{ }$ & $\sqrt{ }$ \\
\hline
\end{tabular}


Table 4. Cont.

\begin{tabular}{|c|c|c|c|c|c|}
\hline Category & Subcategories & YC & YD & STL & APT \\
\hline \multirow{3}{*}{$\begin{array}{c}\text { Ethical values } \\
\quad[15,18]\end{array}$} & $\begin{array}{l}\text { Bamboo cutting is the most } \\
\text { fundamental technique }\end{array}$ & $\sqrt{ }$ & & & \\
\hline & $\begin{array}{c}\text { Be familiar with the characteristics and } \\
\text { limitations of bamboo to produce good } \\
\text { work }\end{array}$ & $\sqrt{ }$ & $\sqrt{ }$ & $\sqrt{ }$ & $\sqrt{ }$ \\
\hline & $\begin{array}{c}\text { Identification and recognition of natural } \\
\text { diversity }\end{array}$ & $\sqrt{ }$ & $\sqrt{ }$ & $\sqrt{ }$ & $\sqrt{ }$ \\
\hline \multirow{3}{*}{$\begin{array}{c}\text { Systems thinking } \\
{[16]}\end{array}$} & $\begin{array}{l}\text { Bamboo techniques from easy to } \\
\text { difficult }\end{array}$ & $\sqrt{ }$ & & & \\
\hline & $\begin{array}{l}\text { A combination of craftsmanship and } \\
\text { artistic expression }\end{array}$ & & $\sqrt{ }$ & $\sqrt{ }$ & $\sqrt{ }$ \\
\hline & $\begin{array}{l}\text { The relationship between the size, } \\
\text { thickness, and product fabrication }\end{array}$ & $\sqrt{ }$ & $\sqrt{ }$ & & \\
\hline \multirow{4}{*}{ Emotions [17] } & $\begin{array}{l}\text { Beginners learn easy techniques, which } \\
\text { gives them a sense of achievement }\end{array}$ & $\sqrt{ }$ & $\sqrt{ }$ & $\sqrt{ }$ & $\sqrt{ }$ \\
\hline & $\begin{array}{c}\text { Plaiting simple, free expression of } \\
\text { beauty }\end{array}$ & & $\sqrt{ }$ & $\sqrt{ }$ & $\sqrt{ }$ \\
\hline & Takes a lot of time and effort to shape & $\sqrt{ }$ & $\sqrt{ }$ & & \\
\hline & $\begin{array}{l}\text { Be patient and follow the steps, fast } \\
\text { plaiting can lead to errors }\end{array}$ & $\sqrt{ }$ & & & \\
\hline
\end{tabular}

In relation to the knowledge dimension, bamboo craftsmen tend to focus on bamboo species and characteristics and bamboo plaiting. Only a few assign importance to knowledge about the cutting of bamboo strips, such as $Y C$, which is caused by the culture heritage department and bamboo craftsmen's personal backgrounds. Referring to the practical skills dimension, the focus of the bamboo craftsmen remains on skills related to the basic rules of bamboo plaiting and the application of bamboo in life. A small number of bamboo craftsmen take into account bamboo cutting skills and tool usage, which is too difficult for students learning in university. Considering the ethical values, bamboo craftsmen referring to this dimension were familiar with the characteristics and limitations of bamboo to produce good work and the identification and recognition of natural diversity. Issues related to the systems thinking dimension were related to craftsmanship and artistic expression. A few bamboo craftsmen took into account other systems thinking concerns, such as a bamboo technique advancement system and the relationship between bamboo strip size and product. Finally, the emotions dimension is characterized by learning easy technique through which they obtain a sense of achievement. In short, bamboo craftsmen assign more relevance to the basics of bamboo technique and simple bamboo procedures, quickly giving a sense of accomplishment, than to the more difficult techniques, such as cutting bamboo strips, making a shape on bamboo with a knife, and craft surface treatment to make decorations.

4.2.2. ESD Evaluation Criteria for the Four Bamboo Courses: The Different Student Learning Effects of Sustainable Development

1. YC: knowing bamboo tools, controlling strength, mastering bamboo plaiting and mutual help among students of primary and advanced levels.

Generally speaking, the motivations of YC students who are influenced by cultural heritage is as follows: (1) they have taken other courses on traditional crafts before and are interested in developing more skills; (2) they have been recommended the courses by elder students; (3) they are available for the course; (4) they have taken several bamboo plaiting courses and admire their teachers very much; (5) they feel very healing and relaxing when plaiting bamboo; and (6) the community offers bamboo plaiting courses at a cost so students prefer to learn in university. These students can basically be divided into three groups: (1) students taking the course for the first time; (2) students taking the course for the second or third time; and (3) senior students who have taken more than three courses. 
Students taking the course for the first time were completely unfamiliar with the operation of bamboo plaiting, some of whom had seen bamboo baskets and chairs in the houses of the elderly but had never used them. These students gradually acquired a basic understanding of bamboo plaiting materials and tools, and their interest was aroused after they found that the technique was not as difficult as they imagined. In the process of plaiting, their eyes ached, and they forgot the plaiting methods from time to time, but their teachers taught them patiently and guided them to find the plaiting rules slowly. Some of the students taking the course for the second or third time learned to dissect bamboo and handle the bamboo strips well. These students have not yet finished their work. When they return to take classes, their teachers will ask them what they want to learn going forward. Part of the course is to learn how to cut a two-section bamboo branch, and the other part is to plait baskets of complex patterns. Regarding the practice of bamboo cutting, the teacher first demonstrates each step, and the students slowly adapt the methods of bamboo cutting according to the correct method taught by the teacher. Bamboo strip processing starts from material preparation. The techniques of calculation and plaiting of the width and thickness of bamboo strips should be carefully considered in advance. It cultivates students' rigorous, orderly, and systematic thinking. When in YC, YC-C03 began to learn bamboo plaiting techniques and has been specialized in bamboo craftsmanship since graduation. YC-C03 mentioned that bamboo cutting is what makes her enjoy bamboo plaiting. "I think bamboo plaiting is a very interesting craft, because I like it. My previous experience was that plaiting will be limited by materials, which is true. Later, when the teacher teaches bamboo cutting and gives me bamboo tube, I am not limited by materials by preparing materials I need" (interviewee YC-C03, 2018/01/03). Students who have been regularly trained by bamboo plaiting teachers in university will appreciate the skills of bamboo art in the actual field, make outdoor devices with free plaiting in practice, learn to apply what they have learned, have a better understanding of bamboo technique, and recognize the link between traditional culture and local sites.

2. YD: learning the relationship between bamboo art and design, using tools to shape bamboo materials, and testing resources and ability.

This course is offered in the fourth academic year of $\mathrm{YD}$, but in fact, students of all grades in all departments are allowed to take it, from YC/YD, the Department of Industrial Design, the Department of Visual Communication Design, and so on. More than half of the students are junior and senior students of the design department, most of whom come to the class because they are interested in handicrafts or they are available when the course is offered. The motivations for selecting the course are as follows: (1) they have seen finished bamboo products and want to know the manufacturing process; (2) they are interested in bamboo crafts and enjoy the texture of bamboo; (3) bamboo represents Taiwan's culture, but they are not familiar with the tradition; (4) they want to know more about bamboo crafts, which may be used in their future creations; (5) they enjoy handicraft courses; (6) they thought the course was about learning bamboo plaiting, and they believed that it was interesting because they used to take DIY experience classes; and (7) they want to learn handwork as the craft courses of YD are well-known. The teacher explains the structure and techniques of traditional bamboo craftsmanship in detail for the students in the first two courses and tells them how to use these practices in modern bamboo craftsmanship and designate methods to transform them. In class, students will learn more about bamboo materials and learn techniques of bamboo cutting and bamboo bending while adding their own creativity to develop the final effect through experimentation and the accumulation of experience regarding the combination of bamboo technique and design. These students are not familiar with bamboo techniques, but they follow the guidance of teachers and conscientiously learn the techniques without neglecting any detail. The creativity of the students of the department of design is influenced by their personality, especially when faced with unfamiliar techniques, and they practice everything taught by their teachers in class, ranging from plaiting and cutting to baking and bending. When the skills are mastered to a certain extent, they unconsciously give full play to their creativity in shape making, and teachers often encourage them to experiment with their shape and 
color preferences. Students gradually become familiar with bamboo materials through experiments, explore the diversity of bamboo crafts, and also test their own technological resources and abilities. They will not turn to their teachers for help unless they have problems beyond their skills, such as the ruptured bamboo. In the interview, one student mentioned that "learning the craft course in university helps them understand the resources they have and their own limitations. Learning to make traditional bamboo-related tools owns the advantages of low price, rapid growth and accessible materials over lacquer, glass and metalworking. The external cost for learning bamboo art is low, and only the input of tools, physical strength and time is needed to start learning." (YD-S12, 2017/12/11). The annual "New Generation" Design Exhibition for Taiwan's design graduates includes process design, which attracts about 10 bamboo-based works designed by students each year. The same is true for YD students. Several senior students come to study bamboo art every semester conscientiously. Not only do they complete the exercises according to the teacher's requirements, but they also experiment and consult the teacher for suggestions. The open discussions with the teacher in class allows the students not only to learn and understand bamboo technique in class, but also to start their students' creative journey and rediscover their enthusiasm and all kinds of possibilities for design.

3. STL: learning about bamboo art materials, knowing historical stories, and experiencing bamboo plaiting techniques.

This course was offered in STL in 2013. Later, the students of the Department of Creative Product Design (DCPD) wanted to use bamboo to make designs for STL. Almost every semester, students of DCPD, who typically account for about half of the total number of students, often stay in the classroom until very late and go to the teacher's studio to practice bamboo dissection after class to further learn bamboo plaiting. Their motivations for selecting the STL bamboo craft course are as follows: (1) Students of DCPD may apply bamboo art to the future creations; (2) they have seen bamboo products, but they have not made such products by themselves; and (3) bamboo art is so interesting that deserves a try. STL has provided a course on bamboo art every semester since2013 for two hours a week. Students are unfamiliar with bamboo materials before they take the course on bamboo art. In an interview, one student said, "It's hard to get in touch with something on which you had no memory in your childhood. Without contact, it is very difficult to have connections. People need emotional connections to feel." (Interviewee STL-S01, 2018/03/09). Students can hear the teacher's explanations of bamboo growth in the course, such as the different density of skin and meat, different hardness, and different usage. In the process of practice, students first watch the teacher's demonstration and then do it on their own, familiarizing themselves with bamboo plaiting by asking the teacher questions. At the same time, the graduation projects of these students receive good comments because of their basic knowledge of the characteristics of bamboo and their good communication with bamboo artists.

4. APT: learning simple bamboo plaiting, adapting to features of bamboo materials, and giving full play to creativity.

APT has seven ceramic firewood kilns of different forms, the guidance of excellent teachers from the tea and ceramics industries, and collaboration between a number of studios and the tea and ceramics industries. The bamboo art course is a compulsory course of APT, which a small number of full-time college students attend, mainly for the improvement of professional skills. In the survey conducted from September 2017 to January 2018, 30 students who had studied bamboo art courses were interviewed, of which 24 were from APT, namely social workers and 6 full-time college students. Their motivations for selecting the course are as follows: (1) Bamboo art teachers are masters, and students have an opportunity to learn from masters; (2) to know people interested in tea and ceramics and make friends with them; and (3) bamboo and tea pottery are very related trades. After demonstrating knowledge of bamboo art and techniques of bamboo cutting, the teacher asks students to split the material by themselves. Only 5-6 students typically want to try cutting bamboo, because everyone understands the difficulty and complexity of bamboo strip processing. They also admire the bamboo 
plaiting technique. Students first complete the basic square-plane plaiting on the table, followed by 2-3 units of shape. Then, they combine and curl them up. After seeing their work, teachers will instruct the students on how to make the shape they want and will think about how to adjust it according to students' needs. Then, they will start to make the shape. They will improve their work by adding a rattan core and fur closure decorations. These students will use bamboo to make tea rules, tea trays, flower sets, and tea needles, especially with silver, because silver will conduct heat. Thus, silver is used inside the product, while bamboo is used outside for insulation.

5. Summary: comparison of student learning effects of sustainable development recognition in the four bamboo courses through ESD evaluation criteria.

Table 5 shows the relationship between the subcategories emerging from the data and the "learning for ESD" framework for professional competencies in ESD. Based on the relationship established between the subcategories that emerged and the ESD competencies framework [37], expectations for "students [in]ESD learning refers to: learning to ask critical questions; learning to clarify one's own values; learning to envision more positive and sustainable futures; learning to think systemically; learning to respond through applied learning; learning to explore the dialectic between tradition and innovation" (see Table 5).This important component of the bachelor's degree course allows students to learn more about how cultural objects are created and how their construction can influence future deterioration, as well as keeping alive a tradition of Taiwan's unique blend of Chinese and local artisan culture. The school employs several nationally recognized craftsmen as external teachers for this part of the teaching program. Naturally, some students show a greater aptitude and interest in a particular medium that allows them to develop their artistic skills beyond what is required for completion of their coursework. The students should be able to acquire the ESD competencies that enable them to cope with the different culture sustainability challenges that current society is facing.

Table 5. Evaluation criteria of four bamboo courses: the relationship between learning for ESD and the subcategories that emerged from student interviews.

\begin{tabular}{|c|c|c|c|}
\hline Learning for ESD [37] & & & Subcategories Emerging from the Data \\
\hline \multirow{4}{*}{ Ask critical questions } & YC & 1. & Know how to recognize the value of manual work \\
\hline & YD & 1. & $\begin{array}{l}\text { Understand that the craft and people are getting are growing } \\
\text { farther apart }\end{array}$ \\
\hline & STL & 1. & $\begin{array}{l}\text { In Taiwan, there are a wealth of crafts and skilled craftsmen who } \\
\text { need us to learn and understand them }\end{array}$ \\
\hline & APT & 1. & Advanced technology, expand horizons \\
\hline \multirow{4}{*}{$\begin{array}{l}\text { Clarify one's own } \\
\text { values }\end{array}$} & YC & $\begin{array}{l}1 . \\
2 .\end{array}$ & $\begin{array}{l}\text { A life of natural quality } \\
\text { Make people close and relax }\end{array}$ \\
\hline & YD & $\begin{array}{l}1 . \\
2 .\end{array}$ & $\begin{array}{l}\text { Natural and fresh temperament } \\
\text { Cultural sustainability should be combined with life application }\end{array}$ \\
\hline & STL & 1. & $\begin{array}{l}\text { More understanding of bamboo crafts can make more } \\
\text { people knowledgeable }\end{array}$ \\
\hline & APT & $\begin{array}{l}1 . \\
2 .\end{array}$ & $\begin{array}{l}\text { Can learn with different craftsmen } \\
\text { Make friends and expand your network }\end{array}$ \\
\hline
\end{tabular}


Table 5. Cont.

\begin{tabular}{|c|c|c|c|}
\hline Learning for ESD [37] & & & Subcategories Emerging from the Data \\
\hline \multirow{4}{*}{$\begin{array}{l}\text { Envision more positive } \\
\text { and sustainable futures }\end{array}$} & YC & $\begin{array}{l}1 . \\
2 .\end{array}$ & $\begin{array}{l}\text { Reasonable structure and material saving } \\
\text { Plaiting techniques can be applied to different materials }\end{array}$ \\
\hline & YD & 1. & $\begin{array}{l}\text { Design creation will not be limited to industrial materials } \\
\text { Bamboo technology has lower cost }\end{array}$ \\
\hline & STL & 1. & More understanding of bamboo crafts makes more people aware \\
\hline & APT & 1. & $\begin{array}{l}\text { Different techniques of pottery, glass, and bamboo can be applied } \\
\text { in pottery, tea ceremonies, and flower paths }\end{array}$ \\
\hline \multirow{4}{*}{ Think systemically } & YC & 1. & $\begin{array}{l}\text { Only after accurate calculation can the work be completed } \\
\text { Strict working procedures }\end{array}$ \\
\hline & YD & 1. & Culture, structure, mechanics, and life \\
\hline & STL & 1. & Culture, technique, and life \\
\hline & APT & 1. & $\begin{array}{l}\text { Different process technologies, tea pottery industry experience, } \\
\text { friends in different fields }\end{array}$ \\
\hline \multirow{4}{*}{$\begin{array}{l}\text { Respond through } \\
\text { applied learning }\end{array}$} & YC & $\begin{array}{l}1 . \\
2 .\end{array}$ & $\begin{array}{l}\text { Experience and understand the process of product making } \\
\text { Achieve their own ideas.Bamboo is tough }\end{array}$ \\
\hline & YD & $\begin{array}{l}1 . \\
2 . \\
3 .\end{array}$ & $\begin{array}{l}\text { Experience is the key to good control } \\
\text { Bamboo is tough and elastic } \\
\text { Bamboo is not as easy to shape as porcelain }\end{array}$ \\
\hline & STL & 1. & $\begin{array}{l}\text { Make emotional connections by familiarizing themselves with } \\
\text { bamboo plaiting }\end{array}$ \\
\hline & APT & 1. & Different crafts are interesting \\
\hline \multirow{4}{*}{$\begin{array}{l}\text { Explore the dialectic } \\
\text { between tradition and } \\
\text { innovation }\end{array}$} & YC & $\begin{array}{l}1 . \\
2 .\end{array}$ & $\begin{array}{l}\text { The plaiting methods are various and varied } \\
\text { Organizing a bamboo products summer camp as a } \\
\text { community activity }\end{array}$ \\
\hline & YD & 2 . & $\begin{array}{l}\text { Teaching foreigners to make bamboo product can be used in } \\
\text { international cultural exchanges } \\
\text { Mastering certain technology can free the expression of } \\
\text { creative ideas } \\
\text { Study the bamboo technique, which may be used later in design }\end{array}$ \\
\hline & STL & 1. & Making more people aware of bamboo culture \\
\hline & APT & 1. & Different creative applications \\
\hline
\end{tabular}




\section{Conclusions}

5.1. There Are Differences in the Position of Bamboo Craft Courses: Teachers' Craftsmanship and Curriculum Orientation Are Different, Resulting in Differences in Technical Depth and Creativity

Based on the above analysis of the teaching methods of bamboo craft courses in four departments of three universities, it is recognized that the teachers and students in different departments have different backgrounds and have different levels of skill and creativity. Students of the YC study bamboo craftsmanship for the preservation and operation of cultural heritage. Bamboo art teachers focus on the improvement of bamboo cutting and plaiting skills, and students can learn a set of rigorous and standardized bamboo plaiting techniques for years, while creativity is something natural with no need to teach. Students of the YD learn bamboo art for the needs of cultural commodity design, so teachers pay attention to the training of bamboo curing, cutting, and other shaping methods, as well as some basic bamboo plaiting techniques. The decomposition of technical wisdom and the interpretation of oriental culture are also taught, and the exploration of creative design is required. Students of STL regard bamboo craftsmanship as a kind of leisure experience, which can be popularized and used. Therefore, while explaining the knowledge and culture of bamboo art, bamboo craftsmanship teachers provide experience packages for students to experience bamboo. Students of APT are majoring in tea pottery design, and they learn bamboo art to increase their understanding of bamboo-made tea materials, which may include bamboo tea trays, bamboo flower vessels, and bamboo tea rules. Therefore, the bamboo craft teachers educate students about the collection of tea table-related bamboo utensils.

Overall, bamboo art learning in design departments tends to be a creative practice, and the learning of bamboo art is moderate: $\mathrm{YC}$ focuses on deep learning of bamboo art, while creativity is something natural with no need to teach; STL sparks interest through the experience of bamboo art, while skills and creativity are not required; and APT studies the manifestations of diverse bamboo art in tea tables and requires a certain degree of basic skills and shaping ability, as is shown in Figure 2.

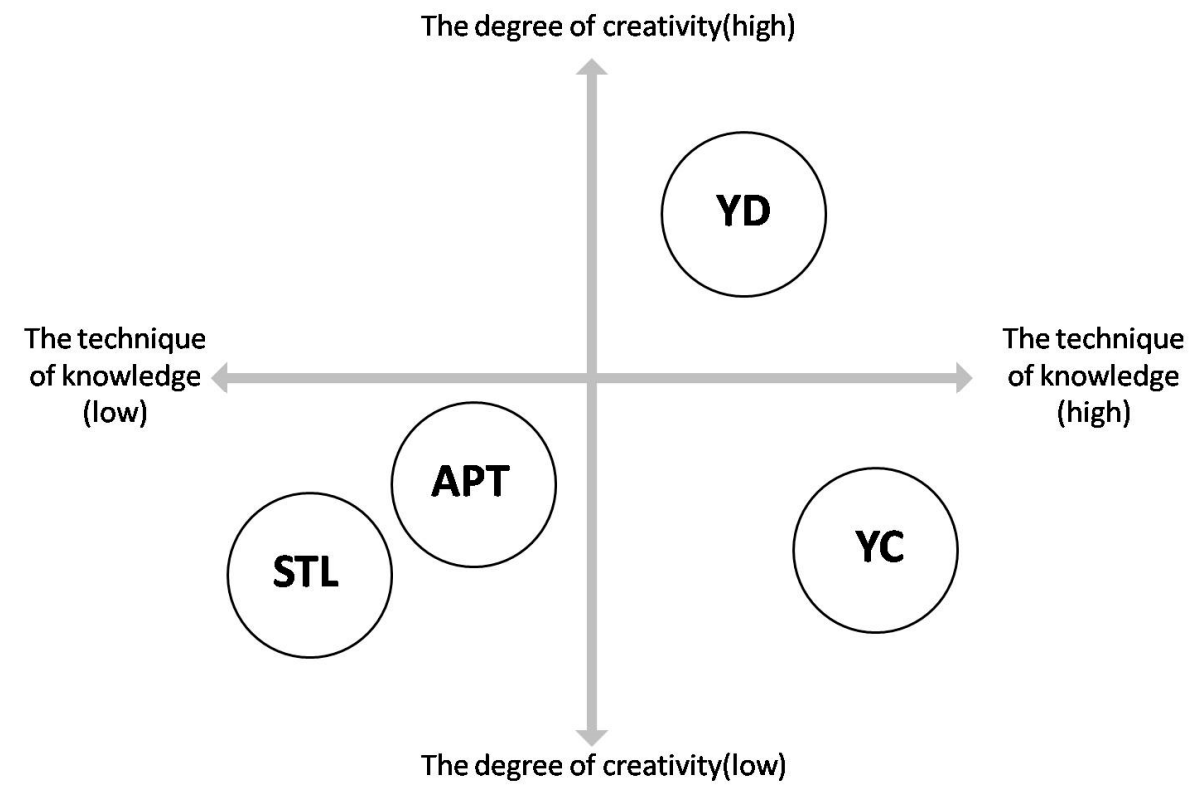

Figure 2. Comparing the techniques and creativity requirements of the courses of study of the four departments of the three schools.

5.2. ESD Evaluation Criteriaof Four Bamboo Craft Courses: Skills Learning Itself is Not Complete, But Provides Students With a Path to Craft Self-Reliance in Confronting CulturalSustainability Challenges

At present, some of the young craftsmanship entrepreneurs in Taiwan are exposed to technique in universities. The young people, who are the minority in the craft industry, spring up in the international community thanks to their distinctive personal characteristics and the marketing and 
aesthetics of Oriental arts and crafts. Relatively speaking, the number of bamboo craft learners in universities is not very large, with a certain degree of rarity. They will be tested as to whether they are talented in craftsmanship when studying in university to see whether they will be competitive in the future. Students do not understand the characteristics of bamboo before they take bamboo art courses. They practice according to the teachers' requirements first, then add some design ideas or apply them to new works. Flexible use of bamboo techniques includes not only the good use of body, but also creative thinking, because a person has experience that did not exist before and has been developed in another learning space. The university can provide students with a possible way to develop their craft workshops or studios independently in the future, so that they can establish a certain foundation of technical knowledge and skills, and pre-estimate the cost of materials, tools, and equipment investment. Taiwan's large-scale industrial transfer of handicraft manufacturing in the 1980s due to the high manual cost has made the process more and more artistic in recent years. The limitation of bamboo technological materials and the high level of technological advancement also hindered the inheritance and development of its talents. Therefore, teaching bamboo techniques is a choice that is not mainstream for departments of materials and crafts in universities, so typically only part-time technical teachers are hired. There is no independent bamboo art specialty, regardless of professional direction and studios.

5.3. The Relationship between ESD and Bamboo Craft Education: Bamboo Craft EducationResponds to the Need forSustainable Concepts and Craft Creation and Universities Offer Opportunities for Testing Students' Technological Talents and Resources, but ESD is Limited and Blurry

Teachers and students in Taiwan's colleges and universities pay close attention to the significance of environmental protection, local culture, and modern life. At the same time, they enhance their learning effectiveness, connect with local industries and society, and prepare for teaching practice and the cultivation of cross-regional creative talents. However, due to the influence of industrial and technological development, the university's view on bamboo craftsmanship is still a position of assisted design, in terms of curriculum time. The practice of bamboo craftsmanship is relatively short, but actually it requires long and sustained training. Moreover, the operators of individual bamboo craftsmanship studios need not only solid skills, but also aesthetic cultivation, cultural knowledge, shaping ability, creative design thinking, and a marketing brand concept. In view of the current teaching practices and promotion of methods of bamboo craftsmanship in universities, students are only allowed to understand bamboo craft on a very fundamental level before they give full play to their creativity. The bamboo crafts courses of the four departments of the three universities in this study address the need for a sustainable concept and craft creation, and their development tendencies are different, as is shown in Figure 3.

Universities offer opportunities for testing students' technological talents and resources, but the course time is limited, except for the multi-semester serial courses of YC. Taiwan's social technological education is so diverse that students interested in bamboo craftsmanship have a choice. There are many courses related to bamboo craftsmanship, such as the improvement of craftsmanship and design ability, intellectual property rights and branding, and courses of bamboo art provided by bamboo craftsmanship development centers, cultural bureaus, community development associations, and personal studios of craftsmen, the cultural and creative industry assistance plan of the Ministry of Culture, technological skill identification test of the Labor Committee, bamboo craftsmanship research association, Nantou bamboo craftsmanship association, activities, and study camps organized by the Taiwan Bamboo Association, as well as learning plans for artists who preserve important cultural heritage and techniques. Although there are many opportunities for further study of bamboo crafts in society, after all, due to the limited personal resources and abilities of college students, they are more likely to participate in the teaching and practice platforms formed by the university and to be guided to develop independently in the future. Therefore, universities may set up social ESD practice plans of cross-regional cooperation for the cultivation of creative talents and bamboo craftsmanship to provide 
more opportunities for college students to participate in the research and cooperation of teachers' craftsmanship, culture, and industry. The knowledge and skills learned in the bamboo craftsmanship course can be better brought into play in social practice to make their learning effective and build students' cultural self-confidence in bamboo craftsmanship.

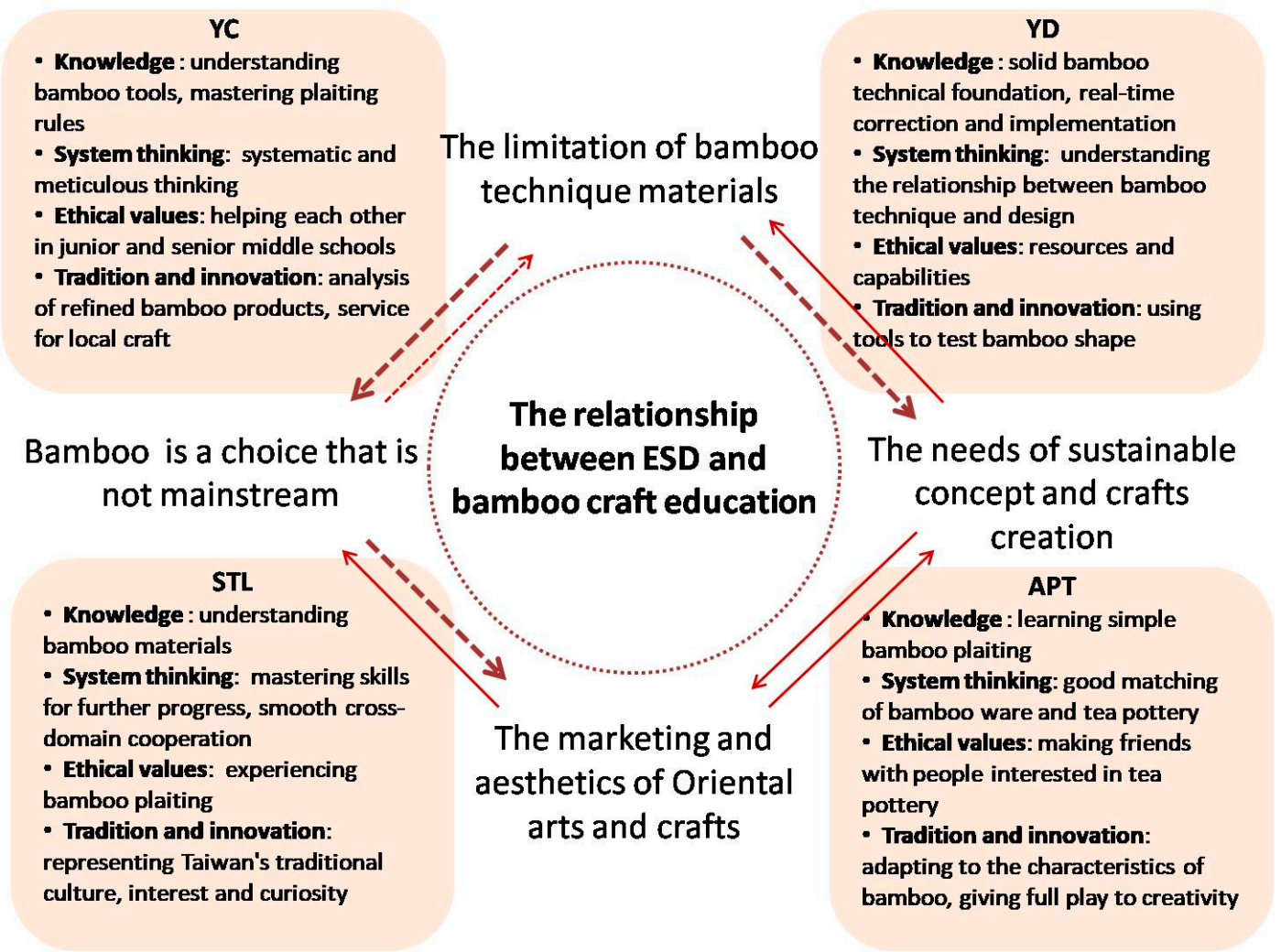

Figure 3. The relationship of between ESD and bamboo craft education.

Author Contributions: Y.D. wrote and revised the manuscript, S.-H.H. conceptualized the project and methodology. Funding: This research received no external funding.

Acknowledgments: The authors would like to express sincere thanks to bamboo craftsman and students.

Conflicts of Interest: The authors declare no conflicts of interest.

\section{References}

1. Wong, S.D. History of the Republic of China-Cultural Development. In History of the Republic of China; National Political University: Taipei, Taiwan, 2011; pp. 140-154.

2. Wong, S.D. New Life Craft: Bamboo Art Industry Special; Chang, C.H., Ed.; Life Aesthetics Museum: Taipei, Taiwan, 2004; pp. 67-68.

3. $\mathrm{Wu}, \mathrm{Z} . \mathrm{W}$. The Changes of Bamboo Craft Impartation and Education in Zhushan. Master's Thesis, Taipei National University of the Arts School of Culture Resources, Taipei, Taiwan, 2016. Unpublished Work.

4. UNESCO. Shaping the Future We Want. UN Decade of Education for Sustainable Development (2005-2014). 2014. Available online: http://unesdoc.unesco.org/images/0023/002301/230171e.pdf (accessed on 14 June 2018).

5. National Taiwan Craft Research Institute (Ed.) Vision-2008 Taiwan Craft Creative Industry; National Taiwan Craft Research Institute: Nantou, Taiwan, 2009; pp. 6-7.

6. Toffler, A.; Alvin, T. The Third Wave; Bantam Books: New York, NY, USA, 1980.

7. Papanek, V. Design for the Real World: Human Ecology and Social Change; Chicago Review Press: Chicago, IL, USA, 2005.

8. Brundtland Commission. Defining Sustainable Development: The World Commission on Environment and Development; Earthscan/Routledge: Oxford, UK, 2014. 
9. Rosalyn, M. Education for Sustainable Development Toolkit. Available online: http://www.esdtoolkit.org (accessed on 20 July 2018).

10. Cheng, Y.J. Green Design; Republic of China Foreign Trade Development Association: Taipei, Taiwan, 1995.

11. Kiyoshi, M. The "Culture and Industries" Seminar and Essays of the Exchanges of Community Empowerment between R. O. C. and Japan; Taiwan Provincial Handicraft Research Institute: Nantou, Taiwan, 1995.

12. Chu, K.C. Traditional handicraft, Green design, Appropriate design, and Design education. Chaoyang J. Des. 2004, 4, 57-71.

13. Lambrechts, W.; Mulà, I.; Ceulemans, K.; Molderez, I.; Gaeremynck, V. The integration of competences for sustainable development in higher education: An analysis of bachelor programs in management. J. Clean. Prod. 2013, 48, 65-73. [CrossRef]

14. Rychen, D.S. Key Competencies for the Knowledge Society. A contribution from the OECD project definition and selection of competencies (DeSeCo). Presented at the Conference: Education-Lifelong Learning and the Knowledge Economy, Stuttgart, Germany, 9-10 October 2002.

15. Corcoran, P.B.; Wals, A. Higher Education and the Challenge of Sustainability; Problematics, Promise and Practice; Kluwer Academic Publishers: Dordrecht, The Netherlands; Boston, MA, USA; London, UK, 2004.

16. Weinert, F.E. Concept of Competence: A Conceptual Clarification; Defining and Selecting Key Competencies; Hogrefe \& Huber: Cambridge, MA, USA; Göttingen, Germany, 2001; pp. 45-66.

17. Norman, D.A. Emotional Design: Why We Love (or Hate) Everyday Things; Basic Books: New York, NY, USA, 2005; pp. 6-27.

18. Cotton, D.R.E.; Winter, J. It's not just Bits of Paper and Light Bulbs: A review of Sustainability Pedagogies and their Potential for use in Higher Education. In Sustainability Education: Perspectives and Practice across Higher Education; Earthscan: London, UK, 2010.

19. Cebrián, G.; Junyent, M. Competencies in Education for Sustainable Development: Exploring the Student Teachers' Views. Sustainability 2015, 7, 2768-2786. [CrossRef]

20. McDonough, W.; Braungart, M. Cradle to Cradle: Remaking the Way We Make Things; North Point Press: New York, NY, USA, 2010.

21. Chen, T.S. Bamboo Crafts_Green Earth 2009 Taiwan Japan Bamboo Crafts Show; National Taiwan Craft Research Institute: Nantou, Taiwan, 2009; pp. 10-11.

22. Chen, C.C. Bamboo Plaiting Craft; Hanguang Culture: Taipei, Taiwan, 1998.

23. EDS Bamboo Design Project of Musashino Art University Research Promotion Center. Available online: http://www.musabi.ac.jp/bambooproject/english/overview.html (accessed on 10 October 2018).

24. Cheng-Long Wetland International Environmental Art Project. Available online: http://artproject4wetland. wordpress.com/ (accessed on 10 October 2018).

25. Yang, J. The history of establishment of "Nantou handicraft seminar" by Shui-Long Yen in 1950s and his achievements. J. Des. 2015, 20, 25-47.

26. Lin, B.X. Process design for activating cultural and creative industries. Arts Apprec. 2011, 7, 14-18.

27. Huang, J.N. Looking at Taiwan's contemporary traditional crafts from the historical track. Tradit. Arts. 2014, 115, 92-101.

28. Hwang, S.H.; Liu, C.H. Promoting the Community Empowerment and Network Governance through Craft Movement-Taking Two Taiwan Ceramic Workshops as Case Studies. Sci. Des. Bull. JSSD. 2016, 63, 11-19.

29. Lin, Z.Y. Craft Fashion "Yii" Album; National Taiwan Craft Research Institute: Nantou, Taiwan, 2011; pp. 10-21.

30. Wang, Y. Introduction to Craft Education; Xing Hua Publications: Taichung, Taiwan, 1971.

31. Shen, T.L. A study of creativity instructional design and practice. Curric. Instr. Q. 2005, 8, 55-71.

32. Ruan, J.L. Teaching value of craft education. Educ. Mon. 1979, 150-151.

33. Lin, T.Y. The cultivation of curators: Examining the US principles and standards. J. Des. 2013, 18-19.

34. Maxwell, J.A. Qualitative Research Design: An Interactive Approach; Sage Publications: Thousand Oaks, CA, USA, 2012.

35. University Curriculum Resources Net. Available online: http://ucourse-tvc.yuntech.edu.tw/WebU/index.aspx (accessed on 10 June 2018).

36. Chen, J.F.; Lin, S.F.; Chen, J.Y. Bamboo Art Museum Collection; Nantou County Government Cultural Bureau: Nantou, Taiwan, 2007. 
37. UNECE. Learning for the Future: Competences in Education for Sustainable Development; UNECE: Geneva, Switzerland, 2012. Available online: http://www.unece.org/fileadmin/DAM/env/esd/ESD_Publications/ Competences_Publication.pdf (accessed on 5 February 2019). (CC BY) license (http://creativecommons.org/licenses/by/4.0/). 